\title{
POLA KONSUMSI PANGAN RUMAH TANGGA PADA DESA PELAKSANA DAN BUKAN PELAKSANA PROGRAM PERCEPATAN PENGANEKARAGAMAN KONSUMSI PANGAN (P2KP) DI KABUPATEN PRINGSEWU
}

\author{
(Household Food Consumption Pattern in Implementing Village and Not Implementing Program for The \\ Acceleration of Food Consumption Instructions in Pringsewu District)
}

Meri Handayani, Wuryaningsih Dwi Sayekti, Raden Hanung Ismono

\begin{abstract}
Jurusan Agribisnis, Fakultas Pertanian, Universitas Lampung, J1. Prof. Dr. Soemantri Brojonegoro No. 1 Bandar Lampung 35145, Telp. 0895349331589,e-mail : meriahmad23@gmail.com
\end{abstract}

\begin{abstract}
This research aims to analyze the pattern of food consumption, the pattern of processed local food consumption, and factors that affected the pattern of household food consumption in Pringsewu district. This research was conducted by survey method. Location of this research was determined purposively in Margosari Village North Pagelaran subdistrict as program implementers and Mulyorejo Village Banyumas subdistrict are not program implementers. The amount of research samples in this research was as many as 74 households who were selected by simple random sampling. The data was collected in month of Apri-May 2017. The data was analyzed by descriptive statistic analysis, and verification analysis by demand consumption function model. The result showed that the amount of energy consumption of Margosari village was 5,474.17 kcal/household/day and household energy consumption of Mulyorejo village was 4,745.22 kcal/household/day with their Desirable Dietary Pattern (DDP) score 78.24 and 68.96. Fried bananas was locally processed food sources of energy consumed and have the largest consumption frequency. Cassava was a local food that has the most processed product. Most of household got the processed local food by making them self. The pattern of household food consumption in Pringsewu district was influenced by the household income and number of household's member.
\end{abstract}

Key words: consumtion pattern, Desirable Dietary Pattern (DDP) score, local food

\section{PENDAHULUAN}

Indonesia masih menghadapi masalah tingginya ketergantungan masyarakat pada beras. Dominasi beras yang tinggi dalam pola konsumsi pangan penduduk Indonesia merupakan salah satu penyebab masih rendahnya kualitas konsumsi pangan nasional, yang belum beragam bergizi seimbang yang diindikasikan oleh Skor Pola Pangan Harapan (PPH). Berdasarkan Badan Pusat Statistik (2014) rata-rata konsumsi padi-padian (beras) oleh masyarakat Indonesia per kapita per hari sejak tahun 2012 hingga tahun 2014 mengalami penurunan. Idealnya, apabila konsumsi beras menurun diharapkan dapat disubtisusi dengan pangan pokok lainnya yang berbasis sumberdaya lokal seperti komoditas umbi-umbian dan padi-padian lainnya.

Komoditas umbi-umbian dan padi-padian sumber karbohidrat lainnya yang biasa dikonsumsi masyarakat di masa lampau semakin tergeser sejalan dengan perkembangan ekonomi dan teknologi. Sementara itu, keberagaman jenis dan keseimbangan gizi dalam pola konsumsi pangan dibutuhkan tubuh untuk hidup sehat, aktif, dan produktif. Dengan memperhatikan pola konsumsi pangan masyarakat Indonesia yang masih belum sesuai harapan tersebut, maka penganekaragaman konsumsi pangan atau diversifikasi konsumsi pangan menjadi penting untuk dilaksanakan guna menciptakan sumberdaya manusia yang lebih berkualitas dan berdaya saing (Badan Ketahanan Pangan Republik Indonesia 2012). Upaya peningkatan diversifikasi pangan dimaksudkan untuk meningkatkan ketersediaan dan konsumsi pangan yang beragam dan bergizi seimbang, dan menghindari ketergantungan pada satu jenis pangan pokok seperti beras. Kebijakan diversifikasi pangan sudah dimulai sejak tahun 1974 melalui Instruksi Presiden (Inpres) Nomor 14 tahun 1974 tentang Usaha Perbaikan Menu Makanan Rakyat (UPMMR), namun demikian hingga saat ini hasilnya belum sesuai dengan harapan.

Menurut Dewi dan Ginting (2012), Indonesia memiliki produksi tanaman pangan non beras yang melimpah, hal ini merupakan salah satu peluang besar dalam pengembangan diversifikasi pangan 
berbasis pangan lokal. Pangan lokal dapat dijadikan pangan pokok alternatif pengganti beras karena memiliki kandungan zat gizi yang tinggi dan tidak kalah dibandingkan kandungan zat gizi pada beras selain itu, pangan berbasis pangan lokal sudah dikenal dan dapat diterima masyarakat. Pangan lokal dapat berupa pangan segar maupun pangan yang telah mengalami pengolahan dengan cara atau metode tertentu dengan atau tanpa bahan tambahan.

Percepatan Penganekaragaman Konsumsi Pangan (P2KP) merupakan upaya implementasi dari Peraturan Presiden Nomor 22 Tahun 2009 Tentang Kebijakan Percepatan Penganekargaman Konsumsi Pangan Berbasis Sumber Daya Lokal, yang ditinjaklanjuti oleh Peraturan Menteri Pertanian Nomor 43 Tahun 2009 Tentang Gerakan Percepatan Penganekaragaman Konsumsi pangan dengan cepat melalui basis kearifan lokal serta kerja sama terintegrasi antara pemerintah, pemerintah daerah, dan masyarakat. Secara umum tujuan kegiatan P2KP adalah untuk memfasilitasi dan mendorong terwujudnya pola konsumsi pangan masyarakat yang beragam, bergizi seimbang, dan aman (B2SA) yang diindikasikan dengan meningkatnya skor PPH. Program P2KP telah dimulai sejak tahun 2010 di Provinsi Lampung. Daerah di Provinsi Lampung yang telah tercakup gerakan P2KP adalah Kabupaten Pringsewu dan Pekon Margosari merupakan salah satu pekon di Kabupaten Pringsewu yang telah tercakup dan melaksanakan seluruh program P2KP.

Terdorong dari tujuan umum gerakan P2KP maka pola konsumsi masyarakat yang telah tercakup program P2KP perlu diamati untuk mengukur adopsinya terhadap pelaksanaan program. Dalam penelitian ini dilakukan pengukuran pola konsumsi pangan rumah tangga Pekon Margosari yang telah tercakup program P2KP dan rumah tangga Pekon Mulyorejo yang belum tercakup program P2KP. Pengukuran tersebut dilakukan dengan melihat skor $\mathrm{PPH}$, sedangkan untuk melihat pengaruh program maka akan dilihat skor $\mathrm{PPH}$ antara rumah tangga Pekon Margosari yang telah tercakup program P2KP dan rumah tangga Pekon Mulyorejo yang belum tercakup program P2KP. Menurut Harper, Deaton dan Driskel (1985) ketersediaan, pola sosial budaya, dan faktor pribadi merupakan faktor-faktor yang mempengaruhi pola konsumsi atau kebiasaan makan baik individu pada tingkat masyarakat maupun rumah tangga. Pola konsumsi pangan lokal dapat dilihat dalam jumlah, frekuensi, dan jenis. Penelitian ini bertujuan untuk menganalisis pola konsumsi pangan rumah tangga dan pola konsumsi pangan lokal serta mengetahui faktor-faktor yang mempengaruhi pola konsumsi pangan rumah tangga Kabupaten Pringsewu.

\section{METODE PENELITIAN}

Penelitian ini dilakukan dengan menggunakan metode survai. Lokasi penelitian dipilih secara sengaja (purposive), yaitu Pekon Margosari Kecamatan Pagelaran Utara dan Pekon Mulyorejo Kecamatan Banyumas. Pemilihan lokasi tersebut didasarkan pertimbangan bahwa Pekon Margosari merupakan pekon di Kabupaten Pringsewu yang telah tercakup program P2KP dan Pekon Mulyorejo merupakan pekon yang belum tercakup program $\mathrm{P} 2 \mathrm{KP}$.

Populasi dalam penelitian ini adalah seluruh rumah tangga di dua pekon. Unit analisis penelitian ini adalah rumah tangga dan responden pada penelitian ini adalah ibu rumah tangga. Penentuan jumlah sampel dalam penelitian ini di dasarkan pada rumus perhitungan sampel Isacc dan Micheal (1995) dalam Sugiarto dkk (2003), yaitu:

$\mathrm{n}=\frac{\mathrm{NZ}^{2} \mathrm{~S}^{2}}{\mathrm{Nd}^{2}+\mathrm{Z}^{2} \mathrm{~S}^{2}}$

Keterangan :

$\mathrm{n} \quad=$ Jumlah sampel rumah tangga

$\mathrm{N}=$ Jumlah populasi rumah tangga

$S^{2}=$ Variasi sampel $(5 \%=1,96)$

$\mathrm{Z}=$ Tingkat kepercayaan $(95 \%=1,96)$

$\mathrm{D}=$ Tingkat kepercayaan $(5 \%=0,05)$

Populasi pada penelitian ini berjumlah 923 rumah tangga, dari perhitungan tersebut diperoleh sampel sebanyak 74 rumah tangga yang terbagi menjadi 39 rumah tangga di Pekon Margosari dan 35 rumah tangga di Pekon Mulyorejo. Teknik pengambilan sampel yang digunakan adalah simple random sampling. Data yang digunakan adalah data primer dan sekunder. Data primer antara lain data karakteristik responden, pendapatan rumah tangga, dan konsumsi pangan rumah tangga. Data sekunder diperoleh dari lembaga antara lain Badan Ketahanan Pangan Daerah Kabupaten Pringsewu, publikasi, dan sumber pustaka lain yang berhubungan dengan penelitian ini. Data jumlah dan jenis pangan rumah tangga dikumpulkan dengan menggunakan metode recall selama 24 jam dan dilakukan selama dua hari tidak berturut-turut, sedangkan untuk melihat konsumsi pangan lokal 
olahan diukur dengan menggunakan metode recall selama satu minggu terakhir.

Metode analisis yang digunakan terdiri analisis statistik deskriptif dan analisis verifikatif dengan model fungsi permintaan konsumsi. Tujuan pertama mengenai pola konsumsi pangan rumah tangga secara umum dan pola konsumsi pangan lokal olahan oleh rumah tangga dianalisis menggunakan analisis statistik deskriptif. Tujuan kedua mengenai faktor-faktor yang mempengaruhi pola konsumsi pangan dianalisis menggunakan analisis model fungsi permintaan konsumsi. Hasil recall mengenai konsumsi pangan rumah tangga dikonversikan kedalam energi kemudian dirataratakan dalam satu hari. Perhitungan kandungan gizi bahan makanan digunakan rumus (Hardinsyah dan Martianto, 1989) yaitu:

$\mathrm{KG}_{\mathrm{ij}}=\left(\frac{\mathrm{B}_{\mathrm{j}}}{100} \times \mathrm{G}_{\mathrm{ij}} \times \frac{\mathrm{BDD}_{\mathrm{j}}}{100}\right)$

Keterangan:

$\mathrm{KG}_{\mathrm{ij}}=$ Kandungan energi pangan

$\mathrm{B}_{\mathrm{j}} \quad=$ Berat pangan (gram) yang dikonsumsi RT

$\mathrm{G}_{\mathrm{ij}}=$ Kandungan energi (gizi) dalam 100 gram pangan

$\mathrm{BDD}_{\mathrm{j}}=$ Persen jenis pangan yang dapat dimakan

Angka kecukupan energi (AKE) individu yang dianjurkan dihitung dengan rumus:

$\mathrm{AKE}-\mathrm{i}=\left(\frac{\mathrm{BB}(\mathrm{kg})}{\mathrm{BB} \operatorname{standar}(\mathrm{kg})} \times \mathrm{AKE}\right.$ standar $)$.

Keterangan:

$\mathrm{AKE}=$ Angka kecukupan energy

$\mathrm{BB}=$ Berat badan individu

BB standar $=$ Berat badan standar

ALE standar = Angka kecukupan energi dalam tabel kecukupan gizi yang dianjurkan menurut hasil Widya Karya Nasional Pangan dan Gizi $\mathrm{X}$ tahun 2012

AKE-rt $=$ Jumlah AKE-i

Angka kecukupan energi rumah tangga (AKE-rt) adalah jumlah AKE-i seluruh anggota rumah tangga

Tingkat kecukupan energi rumah tangga :

$\mathrm{TKE}=\frac{\mathrm{A}}{\mathrm{B}} \mathrm{X} 100 \%$
Keterangan:

TKE $=$ Tingkat kecukupan energi

$\mathrm{A}=$ Konsumsi energi RT

$\mathrm{B}=\mathrm{AKE}$ rumah tangga

Perhitungan selanjutnya adalah menentukan skor PPH dengan persamaan 6 dan 7 .

Skor PPH per golongan pangan

$=\frac{\text { Konsumsi Energi }}{\mathrm{AKE}} \times$ nilai bobot

Skor $\mathrm{PPH}=\Sigma$ Skor PPH sembilan golongan pangan

Keterangan :

Bobot $=$ Nilai bobot masing-masing golongan pangan (Tabel 1)

Model persamaan fungsi umum konsumsi pangan rumah tangga adalah sebagai berikut:

$\mathrm{Y}=\mathrm{b}_{0} \mathrm{X}_{1}{ }^{\mathrm{b} 1} \mathrm{X}_{2}{ }^{\mathrm{b} 2} \mathrm{X}_{3}{ }^{\mathrm{b} 3} \mathrm{X}_{4}{ }^{\mathrm{b} 4} \mathrm{X}_{5}{ }^{\mathrm{b} 5}$.D1.D2.D3.e $\mathrm{e}^{\mathrm{u}}$

$\mathrm{LnY}=\operatorname{Lnb}_{0}+\mathrm{b}_{1} \operatorname{Lnx}_{1}+\mathrm{b}_{2} \operatorname{Lnx}_{2}+\mathrm{b}_{3} \operatorname{Lnx}_{3}+\mathrm{b}_{4} \operatorname{Lnx}_{4}+$

$$
\mathrm{b}_{5} \mathrm{Lnx}_{5}+\mathrm{b}_{6} \mathrm{D}_{1}+\mathrm{b}_{7} \mathrm{D}_{2}+\mathrm{b}_{8} \mathrm{D}_{3}+\mathrm{U}
$$

Keterangan:

$\mathrm{Y}=$ Pola konsumsi pangan RT (Skor PPH)

$\mathrm{b}_{0}=$ Bilangan konstan

$\mathrm{b}_{1}-\mathrm{b}_{7}=$ Koefisien regresi

$\mathrm{X}_{1}=$ Ketersediaan pangan lokal

$\mathrm{X}_{2}=$ Pendapatan rumah tangga (Rp/bulan)

$\mathrm{X}_{3}=$ Pendidikan ibu rumah tangga (tahun)

$\mathrm{X}_{4}=$ Usia ibu rumah tangga (tahun)

$\mathrm{X}_{5}=$ Jumlah anggota rumah tangga (orang)

$\mathrm{D} 1=$ Pengetahuan gizi ibu; $\mathrm{D} 1=1$ : tinggi dan 0 : lainnya

D2 = Pengetahuan gizi ibu; D2 = 1 : sedang dan 0: lainnya

D3 = Program $\mathrm{P} 2 \mathrm{KP}$; D3=1 tercakup program dan D3= 0 lainnya

$\mathrm{e} \quad=$ Kesalahan prediksi (standartd error)

Tabel 1. Nilai bobot sembilan golongan pangan

\begin{tabular}{lll}
\hline Golongan Pangan & Bobot & Skor maks \\
\hline Padi-padian & 0,5 & 25,0 \\
Umbi-umbian & 0,5 & 2,5 \\
Pangan Hewani & 2,0 & 24,0 \\
Sayur dan buah & 5,0 & 30,0 \\
Minyak dan lemak & 0,5 & 5,0 \\
Buah/biji berminyak & 0,5 & 1,0 \\
Kacang-kacangan & 2,0 & 10,0 \\
Gula & 0,5 & 2,5 \\
Lain-lain & 0,0 & 0,0 \\
\hline
\end{tabular}


Pengujian selanjutnya untuk melihat pengaruh variabel bebas terhadap variabel terikat adalah melakukan uji $\mathrm{F}$ dan uji t.

\section{HASIL DAN PEMBAHASAN}

\section{Karakteristik Responden}

Karakteristik responden dalam penelitian ini diuraikan berdasarkan usia, tingkat pendidikan, tingkat pengetahuan gizi, jumlah anggota rumah tangga, pekerjaan, dan pendapatan rumah tangga. Jumlah responden seluruhnya adalah 74 ibu rumah tangga. Berdasarkan hasil penelitian menyatakan bahwa, sebagian besar ibu rumah tangga di Kabupaten Pringsewu berusia antara 34-47 (44,59\%), tingkat pendidikan dengan tahun sukses antara 0-6 tahun $(47,29 \%)$, tingkat pengetahuan gizi sebagian besar berada pada kategori rendah $(37,83 \%)$, jumlah anggota rumah tangga empat orang $(41,89 \%)$, pekerjaan sebagai ibu rumah tangga $(56,75 \%)$ dan sebagian besar pendapatan rumah tangga berkisar antara Rp200.000,00Rp1.000.000,00 (62,16\%) per bulan.

\section{Pola Konsumsi Pangan Rumah Tangga}

Pola konsumsi pangan rumah tangga dilihat dari jenis, jumlah, frekuensi konsumsi pangan. Jenis pangan rumah tangga merupakan pangan dari setiap golongan pangan yang paling banyak dikonsumsi rumah tangga di Pekon Margosari dan Pekon Mulyorejo. Jumlah konsumsi masingmasing jenis pangan dilihat dalam satuan $\mathrm{kg}$ per kapita per minggu. Frekuensi konsumsi pangan dilihat dari frekuensi mengonsumsi berbagai jenis pangan dalam periode satu minggu, dan dikategorikan mengacu pada teori Suhardjo (1989) dalam Yusty (2013). Hasil penelitian menunjukkan, jenis pangan yang dikonsumsi rumah tangga di Pekon Margosari dan di Pekon Mulyorejo relatif sama.

Tabel 2. Jenis konsumsi pangan rumah tangga di Kabupaten Pringsewu

\begin{tabular}{lll}
\hline \multicolumn{1}{c}{ Golongan Pangan } & \multicolumn{1}{c}{$\begin{array}{c}\text { Pekon } \\
\text { Margosari }\end{array}$} & \multicolumn{1}{c}{$\begin{array}{c}\text { Pekon } \\
\text { Mulyorejo }\end{array}$} \\
\hline Padi-padian & Beras & Beras \\
Umbi-umbian & Ubi kayu & Ubi kayu \\
Hewani & Telur & Telur \\
Sayur dan buah & Cabai, Pisang & Cabai, Pisang \\
Kacang-kacangan & Tempe & Tempe \\
Minyak dan lemak & Minyak goreng & Minyak goring \\
Buah biji berminyak & Santan kelapa & Santan kelapa \\
Gula & Gula pasir & Gula pasir \\
Lain-lain & Teh & Kopi \\
\hline
\end{tabular}

Tabel 3. Jumlah konsumsi pangan rumah tangga di Kabupaten Pringsewu

\begin{tabular}{|c|c|c|c|c|}
\hline \multirow{2}{*}{$\begin{array}{c}\text { Golongan } \\
\text { Pangan }\end{array}$} & \multicolumn{2}{|c|}{ Pekon Margosari } & \multicolumn{2}{|c|}{ Pekon Mulyorejo } \\
\hline & $\begin{array}{l}\text { Jenis } \\
\text { Pangan }\end{array}$ & $\begin{array}{l}\mathrm{kg} / \mathrm{kap} / \\
\text { minggu }\end{array}$ & $\begin{array}{l}\text { Jenis } \\
\text { Pangan }\end{array}$ & $\begin{array}{l}\mathrm{kg} / \mathrm{kap} / \\
\text { minggu }\end{array}$ \\
\hline $\begin{array}{l}\text { Padi- } \\
\text { padian }\end{array}$ & Beras & 1,73 & Beras & 1,56 \\
\hline Umbi- & Ubi & & Ubi & \\
\hline umbian & kayu & 0,13 & kayu & 0,04 \\
\hline Hewani & Telur & 0,14 & Telur & 0,11 \\
\hline Sayur dan & Cabe & 0,01 & Cabe & 0,01 \\
\hline $\begin{array}{l}\text { buah } \\
\text { Kacang- }\end{array}$ & Pisang & 0,29 & Pisang & 0,10 \\
\hline kacangan & Tempe & 0,33 & Tempe & 0,32 \\
\hline $\begin{array}{l}\text { Minyak } \\
\text { dan lemak }\end{array}$ & $\begin{array}{l}\text { Minyak } \\
\text { goreng }\end{array}$ & 0,01 & $\begin{array}{l}\text { Minyak } \\
\text { goreng }\end{array}$ & 0,04 \\
\hline Buah biji & Santan & & Santan & \\
\hline berminyak & $\begin{array}{l}\text { kelapa } \\
\text { Gula }\end{array}$ & 0,02 & $\begin{array}{l}\text { kelapa } \\
\text { Gula }\end{array}$ & 0,04 \\
\hline Gula & pasir & 0,03 & pasir & 0,03 \\
\hline Lain-lain & Kopi & 0,01 & Kopi & 0,00 \\
\hline
\end{tabular}

Jenis pangan yang banyak dikonsumsi rumah tangga kedua pekon adalah beras, ubi kayu, telur ayam ras, cabai, pisang, tempe, minyak goreng, santan kelapa, gula pasir kopi dan teh (Tabel 2).

Berdasarkan hasil penelitian diketahui bahwa, ratarata jumlah konsumsi beras per kapita per minggu rumah tangga Pekon Margosari sebesar 1,73 kg/kapita/minggu dan Pekon Mulyorejo 1,56 $\mathrm{kg} /$ kapita/minggu. Konsumsi beras Pekon Margosari lebih tinggi bila dibandingkan konsumsi beras nasional pada tahun 2016 yaitu mencapai 1,668 kg/kapita/minggu (Badan Pusat Statistik 2017). Jumlah konsumsi masing-masing jenis pangan rumah tangga di pekon penelitian dapat dilihat pada Tabel 3 .

Jumlah konsumsi pada golongan pangan hewani rumah tangga di kedua pekon masih lebih kecil dibandingkan dengan data konsumsi pangan nasional tahun 2016. Konsumsi telur ayam ras/kampung berdasarkan data konsumsi pangan nasional tahun 2016 sebesar 0,198 $\mathrm{kg} / \mathrm{kapita} /$ minggu, sedangkan hasil penelitian menunjukkan konsumsi telur pada rumah tangga Pekon Margosari baru mencapai 0,14 $\mathrm{kg} /$ kapita/minggu dan Pekon Mulyorejo 0,11 $\mathrm{kg} / \mathrm{kapita} / \mathrm{ming} g \mathrm{u}$. Berbeda dengan jumlah konsumsi beras dan jenis pangan hewani lainnya, tempe merupakan jenis pangan dari golongan kacang-kacangan yang dikonsumsi rumah tangga di Pekon Margosari mencapai 0,33 $\mathrm{kg} / \mathrm{kapita} /$ minggu dan Pekon Mulyorejo 0,32 $\mathrm{kg} / \mathrm{kapita} / \mathrm{ming} g \mathrm{u}$, jumlah tersebut lebih besar dibandingkan dengan data konsumsi nasional pada 
tahun 2016 yaitu mencapai 0,141 $\mathrm{kg} / \mathrm{kapita/minggu}$.

Frekuensi konsumsi rumah tangga di Pekon Margosari dan Pekon Mulyorejo relatif sama, yaitu berupa beras, cabe, minyak goreng, gula dan kopi dominan dikonsumsi rumah tangga pada frekuensi sering. Sebagian besar rumah tangga di pekon penelitian mengonsumsi telur pada frekuensi cukup. Pisang dikonsumsi sebagian besar rumah tangga di Pekon Margosari dalam frekuensi sering, sedangkan rumah tangga di Pekon Mulyorejo dalam frekuensi jarang. Ubi kayu dikonsumsi sebagian besar rumah tangga di Pekon Margosari dalam frekuensi cukup, dan di Pekon Mulyorejo dalam frekuensi jarang (Tabel 4).

Berdasarkan hasil penelitian total konsumsi energi rumah tangga di Pekon Margosari adalah sebesar 5.474,17 kkal/rumah tangga/hari dengan TKE sebesar 68,64 persen, dan 4.745,22 kkal/rumah dengan TKE sebesar 66,05 persen pada rumah tangga di Pekon Mulyorejo. Hasil tersebut menunjukkan bahwa tingkat kecukupan energi (TKE) rumah tangga di Pekon Margosari dan Pekon Mulyorejo berada pada defisit tingkat berat (<70\% AKG). Departemen kesehatan (1996) dalam Sukandar (2007) yang diacu Yoris (2013).

Berdasarkan hasil penelitian, skor PPH rumah tangga Pekon Margosari menunjukkan nilai yang lebih tinggi dibandingkan skor PPH rumah tangga Pekon Mulyorejo. Skor PPH rumah tangga Pekon Margosari yang tercapai adalah sebesar 78,24 sedangkan skor PPH rumah tangga Pekon Mulyorejo adalah sebesar 68,96. Skor PPH rumah tangga Pekon Margosari dan Pekon Mulyorejo masih jauh dari skor ideal, hal tersebut menunjukkan bahwa konsumsi pangan rumah tangga di daerah tersebut cenderung tidak beragam dan kualitas konsumsi pangan rumah tangga di daerah tersebut masih rendah. Skor Pola Pangan Harapan rumah tangga kedua pekon penelitian masih jauh dari target nasional yaitu 92 persen (Dinas Ketahanan Pangan Kabupaten Pringsewu 2017). Perbandingan skor PPH rumah tangga Pekon Margosari dan rumah tangga Pekon Mulyorejo dapat dilihat pada Tabel 5.

Hasil penelitian Hamid, Setiawan dan Suhartini (2013) yang menganalisis pola konsumsi pangan rumah tangga di Kecamtan Tarakan Barat Kota Tarakan Provinsi Kalimantan Timur menunjukkan bahwa skor PPH pada rumah tangga pedesaan sebesar 60,27 dan 82,14 pada rumah tangga perkotaan. Skor pola pangan harapan $(\mathrm{PPH})$ rumah tangga kedua pekon dalam penelitian ini lebih tinggi dibandingkan skor $\mathrm{PPH}$ rumah tangga pedesaan dan lebih rendah dibandingkan skor PPH rumah tangga perkotaan di Kecamatan Tarakan Barat Kota Tarakan Provinsi Kalimantan Timur.

\section{Pola Konsumsi pangan lokal olahan}

Jumlah konsumsi pangan lokal olahan dalam penelitian ini dilihat dari banyaknya pangan lokal olahan yang dikonsumsi rumah tangga (gram). Jenis pangan lokal olahan dilihat dari banyaknya jenis pangan lokal olahan yang muncul dalam penelitian ini. Frekuensi konsumsi pangan lokal olahan dihitung mengacu pada teori Suhardjo (1989) dalam Yusty (2013), dilihat dari frekuensi mengonsumsi pangan lokal olahan dalam waktu satu minggu. Sumber pangan lokal dilihat berdasarkan asal memperoleh pangan lokal olahan. Dalam menghitung skor frekuensi konsumsi terdapat lima klasifikasi, adapun keterangannya sebagai berikut.

$\begin{array}{rlrr}\text { A } & =\text { Sering } /(>1 \mathrm{x} \text { sehari, } 1 \mathrm{x} & & \\ & \text { sehari, } 4-6 \mathrm{x} / \mathrm{minggu}) & \text { skor } & 50 \\ \mathrm{~B} & =\text { Cukup sering } /(3 \mathrm{x} \text { seminggu }) & \text { skor } & 25 \\ \mathrm{C} & =\text { Cukup }(2 \mathrm{x} / \text { minggu }) & \text { skor } & 15 \\ \mathrm{D} & \text { = Jarang }(<1 \mathrm{x} \text { per minggu }) & \text { skor } & 10 \\ \mathrm{E} & =\text { Tidak pernah } & \text { skor } & 0\end{array}$

Berdasarkan penelitian yang telah dilakukan terdapat berbagai jenis pangan lokal dengan beranekaragam jenis olahan diantaranya jagung rebus, bakwan jagung, beras siger/oyek/tiwul, combro, eyek-eyek, kolak, gaplek, geblek, gethuk, kelanting, keripik ubi kayu, lemet, ubi kayu rebus, ubi kayu goreng, tape ubi kayu, keripik ubi jalar, ubi jalar rebus, ubi jalar goreng, kolak ubi jalar, talas rebus, talas goreng, pisang goreng, pisang rebus, sale pisang, kolak pisang dan keripik pisang. Ubi kayu merupakan jenis pangan lokal dengan jenis olahan terbanyak muncul pada rumah tangga di Pekon Margosari (39,29\%) dan Pekon Mulyorejo (45,00\%). Keripik ubi kayu merupakan pangan lokal olahan ubi kayu yang dikonsumsi rumah tangga di Pekon Margosari dengan jumlah konsumsi tertinggi yaitu 128,21 gram/rumah tangga/minggu, dan oyek atau tiwul dikonsumsi rumah tangga di Pekon Mulyorejo dengan jumlah konsumsi tertinggi yaitu 85,71 gram/rumah tangga/minggu. 
Tabel 4. Frekuensi konsumsi rumah tangga Kabupaten Pringsewu

\begin{tabular}{|c|c|c|c|c|}
\hline \multirow[b]{2}{*}{ Golongan Pangan } & \multicolumn{2}{|c|}{ Pekon Margosari } & \multicolumn{2}{|c|}{ Pekon Mulyorejo } \\
\hline & Jenis Pangan & Frekuensi & Jenis Pangan & Frekuensi \\
\hline Padi-padian & Beras & Sering & Beras & Sering \\
\hline Umbi-umbian & Ubi kayu & Cukup & Ubi kayu & Jarang \\
\hline Hewani & Telur & Cukup & Telur & Cukup \\
\hline Sayur dan buah & Cabe & Sering & Cabe & Sering \\
\hline & Pisang & Sering & Pisang & Jarang \\
\hline Kacang-kacangan & Tempe & Cukup sering & Tempe & Cukup sering \\
\hline Minyak dan lemak & Minyak goring & Sering & Minyak goring & Sering \\
\hline Buah biji berminyak & Santan kelapa & Cukup sering & Santan kelapa & Cukup \\
\hline Gula & Gula pasir & Sering & Gula pasir & Sering \\
\hline Lain-lain & Kopi & Sering & Kopi & Sering \\
\hline
\end{tabular}

Olahan jagung yang memiliki jumlah konsumsi terbesar adalah jagung rebus yaitu 383,33 gram/rumah tangga/minggu di Pekon Margosari, dan 185,71 gram/rumah tangga/minggu di Pekon Mulyorejo. Pisang goreng merupakan pangan lokal olahan yang dikonsumsi rumah tangga di kedua pekon dengan jumlah konsumsi tertinggi yaitu 458,46 gram/rumah tangga/minggu di Pekon Margosari, dan 562,86 gram/rumah tangga/minggu di Pekon Mulyorejo. Ubi jalar rebus menjadi olahan ubi jalar yang dikonsumsi rumah tangga di daerah penelitian dengan jumlah terbesar yaitu 135,90 gram/rumah tangga/minggu di Pekon Margosari, dan180,00 gram/rumah tangga/minggu di Pekon Mulyorejo.

Skor tertinggi dari frekuensi konsumsi pangan lokal olahan pada rumah tangga Pekon Margosari dan rumah tangga Pekon Mulyorejo adalah pisang goreng dengan skor masing-masing 6,26 dan 5,74. Sebagian besar rumah tangga di Pekon Margosari maupun di Pekon Mulyorejo memperoleh pangan lokal olahan dari membuat sendiri, dengan persentase masing-masing $(58,84 \%)$ pada rumah tangga di Pekon Margosari dan $(63,04 \%)$ pada rumah tangga di Pekon Mulyorejo.

\section{Analisis Faktor-Faktor yang Mempengaruhi Pola Konsumsi Pangan Rumah Tangga}

Berdasarkan hasil analisis yang telah dilakukan diperoleh nilai $\mathrm{F}$ hitung sebesar 3,853 dengan probabilitasnya sebesar 0,001 . Hal tersebut menjelaskan bahwa secara bersama-sama variabel ketersediaan $\left(\mathrm{X}_{1}\right)$, pendapatan $\left(\mathrm{X}_{2}\right)$, tingkat pendidikan $\left(\mathrm{X}_{3}\right)$, usia IRT $\left(\mathrm{X}_{4}\right)$, jumlah anggota rumah tangga $\left(\mathrm{X}_{5}\right)$, pengetahuan gizi (D1), pengetahuan gizi (D2) dan program P2KP (D3) berpengaruh sangat nyata terhadap variabel skor PPH (Y) rumah tangga di Kabupaten Pringsewu dengan taraf kepercayaan 99,00 persen. Hasil regresi analisis faktor-faktor yang mempengaruhi pola konsumsi pangan rumah tangga di Kabupaten Pringsewu dapat dilihat pada Tabel 5.

Berdasarkan hasil analisis uji $\mathrm{t}$ terdapat dua variabel yang berpengaruh nyata terhadap pola konsumsi pangan rumah tangga yaitu variabel pendapatan $\left(\mathrm{X}_{2}\right)$ dan jumlah anggota rumah tangga $\left(\mathrm{X}_{5}\right)$. Pendapatan rumah tangga menunjukkan pengaruh yang signifikan dengan taraf signifikan 99 persen, dengan nilai koefisien 0,144.

Hasil penelitian ini sejalan dengan hasil penelitian Pontoh (2011), bahwa besarnya tingkat pendapatan berpengaruh nyata terhadap tingkat konsumsi nelayan di Kecamatan Tenga Kabupaten Minahasa Sulawesi Utara. Pendapatan merupakan cermin dari daya beli sehingga kualitas dan kuantitas barang yang dapat dibeli juga tergantung daya beli. Semakin besar pendapatan yang diterima maka akan semakin besar peluang rumah tangga untuk memilih berbagai jenis pangan yang lebih bervariasi dan meningkatkan kualitas pangannya dengan cara membeli bahan pangan yang nilai gizinya lebih tinggi.

Jumlah anggota rumah tangga menunjukkan pengaruh yang signifikan pada tingkat kepercayaan 95,00 persen dengan nilai koefisien -0,201. Hasi`l penelitian Yuliana, Zakaria, Adawiyah (2013) juga menunjukkan terdapat hubungan negatif antara besar anggota rumah tangga terhadap ketahanan pangan rumah tangga nelayan Kecamatan Teluk Betung Selatan Kota Bandar Lampung. Hasil penelitian ini selaras dengan pendapat (Suyastiri, 2008) yang menyatakan bahwa semakin banyak jumlah anggota rumah tangga maka beban yang akan ditanggung rumah tangga akan semakin besar. 
Tabel 5. Hasil analisis regresi faktor-faktor yang mempengaruhi pola konsumsi pangan rumah tangga Kabupaten Pringsewu

\begin{tabular}{lcc}
\hline \multirow{2}{*}{ Variabel } & \multicolumn{2}{c}{ Kab. Pringsewu } \\
\cline { 2 - 3 } & Koef. Regresi & Sign \\
\hline Konstanta & 1,809 & 0,005 \\
Ketersediaan (X1) & 0,004 & 0,346 \\
Pendapatan (X2) & 0,144 & 0,000 \\
Pendidikan (X3) & 0,003 & 0,974 \\
Usia IRT (X4) & 0,120 & 0,338 \\
Jumlah anggota RT (X5) & $-0,201$ & 0,061 \\
Pengetahuan gizi tinggi (D1) & 0,60 & 0,368 \\
Pengetahuan gizi sedang (D2) & $-0,804$ & 0,236 \\
Program P2KP (D3) & 0,802 & 0,157 \\
\hline F hit & 3,853 & 0,001 \\
$R^{2}$ & 0,238 \\
\hline
\end{tabular}

Terdapat dua cara yang dapat dilakukan untuk mengatasinya, yaitu dengan meningkatkan pendapatan rumah tangga atau mengurangi pengeluaran pangan rumah tangga. Secara matematis model terbaik fungsi pola konsumsi pangan rumah tangga di Kabupaten Pringsewu yang dibentuk adalah:

$\operatorname{LnY}=1,809+0,144 \operatorname{LnX}_{2}-0,201 \operatorname{LnX}{ }_{5}$

\section{KESIMPULAN}

Hasil penelitian ini menunjukkan jenis konsumsi pangan rumah tangga di Kabupaten Pringsewu didominasi oleh beras, ubi kayu, telur ayam ras, cabai, pisang, tempe, minyak goreng, santan kelapa, gula pasir, kopi dan teh. Rata-rata angka konsumsi energi rumah tangga di Pekon Margosari adalah 5.4674,17 kkal/rumah tangga/hari dan 4.754,22 rumah tangga Pekon Mulyorejo dengan skor PPH masing-masing 78,24 dan 68,96. Pisang goreng merupakan jenis pangan lokal olahan yang dikonsumsi rumah tangga di Kabupaten Pringsewu dengan jumlah konsumsi tertinggi, yaitu 458,46 gram/rumah tangga/minggu di Pekon Margosari dan 526,86 gram/rumah tangga/minggu di Pekon Mulyorejo, ubi kayu merupakan bahan baku pangan lokal olahan dengan jenis olahan terbanyak. Frekuensi konsumsi olahan pangan lokal terbesar adalah pisang goreng, yaitu 6,26 di Pekon Margosari dan 5,74 di Pekon Mulyorejo. Sebagian besar rumah tangga di Kabupaten Pringsewu memperoleh pangan lokal olahan dari membuat sendiri. Faktor-faktor yang mempengaruhi pola konsumsi pangan rumah tangga di Kabupaten Pringsewu adalah pendapatan dan jumlah anggota rumah tangga.

\section{DAFTAR PUSTAKA}

Badan Ketahanan Pangan Republik Indonesia. 2012. Roadmap Diversifikasi Pangan 20112015. Edisi Kedua. Jakarta.

BPS [Badan Pusat Statistik].2014. Rata-rata Konsumsi per Kapita Seminggu Beberapa Macam Bahan Makanan Penting, 2007-2016. http//www.bps.go.id/statistictable/2014/09/08/ 950/rata-rata-konsumsi-per-kapita-seminggubeberapa-macam-bahan-makanan-penting-20 07-2016.html. [30 Januari 2018].

Dewi GP dan Ginting AM. 2012. Antisipasi krisis pangan melalui kebijakan diversifikasi pangan. Jurnal Ekonomi \& Kebijakan Publik, 3(1): 65-78. http://jurnal.dpr.go.id/index. php/ekp/article/view/172. [23 Desember 2017]

Hamid Y, Setiawan B, Suhartini. 2013. Analisis pola konsumsi pangan rumah tangga (Studi Kasus di Kecamatan Tarakan Barat Kota Tarakan Provinsi Kalimantan Timur). Jurnal AGRISE, 8(3): 175-190. http://agrise.ub.ac .id/index.php/agrise/article/download/104/131 . [23 Desember 2017].

Hardinsyah D, Martianto. 1989. Cara Menghitung Angka Kecukupan Energi Dan Protein Serta Penilaian Mutu Gizi Konsumsi Pangan. Wirasari. Jakarta.

Harper LJ, Deaton BJ, dan Driskel JA. 1985. Pangan, Gizi dan Pertanian. Diterjemahkan oleh Suhardjo. UI Press, Jakarta.

Pontoh O. 2011. Pengaruh Tingkat pendapatan terhadap pola konsumsi nelayan di Kecamatan Tenga Kabupaten Minahasa Sulawesi Utara. Pacific Journal, 1 (6) : 1038-1040. http:// repo.unsrat.ac.id/338/1/pengaruh_tingkat_pen dapatan_terhadap_pola_konsumsi_nelayan_di _Kecamatan_Tenga_Kabupaten_Minahasa_S elatan_Sulawesi_Utara.Pdf. [04 Januari 2018].

Sugiarto D, Siagian LT, Sunaryanto DS, dan Oetomo. 2003. Teknik Sampling. PT Gramedia Pustaka Utama, Jakarta.

Suyastri. 2008. Diversifikasi konsumsi pangan pokok berbasis potensi lokal dalam mewujudkan ketahanan pangan rumah tangga di Kecamatan Semin Kabupaten Gunung Kidul. Jurnal Ekonomi Pembangunan, 13(1): 51-60. http://jurnal.uii.ac.id/index.php/JEP/ article/view/50. [23 Desember 2017].

Tatipikalawan JM. 2014. Pengaruh Karakteristik sosial ekonomi keluarga terhadap keanekaragaman konsumsi pangan di Kecamatan Letti Kabupaten Maluku Barat Daya Provinsi Maluku. Jurnal Ilmu Ternak 


\section{JIIA, VOLUME 7 No. 1, FEBRUARI 2019}

dan Tanaman, 4(1): 38-44. https:// ejournal.unpatti.ac.id/. [23 Desember 2017].

Yoris L. 2013. Pola konsumsi pangan masyarakat di Kecamatan Lakor di Kabupaten Maluku Barat Daya. Jurnal Ilmu Ternak dan Tanaman (Agrinimal), 3(2): 67-71. https://ejournal.un patti.ac.id/ppr_iteminfo_Ink.php?id=714. [23 Desember 2017].

Yuliana P, Zakaria WA, dan Adawiyah R. 2013. Ketahanan pangan rumah tangga nelayan di
Kecamatan Teluk Betung Selatan Kota Bandar Lampung. JIIA,1(2):181-186. http:// jurnal.fp.unila.ac.id/index.php/JIIA/article/vie w246. [Januari 2018].

Yusty GT. 2013. Analisis Pola Konsumsi Ubi Kayu dan Olahannya Pada Rumah Tangga di Kota Bandar Lampung. Skripsi. Universitas Lampung. Bandar Lampung. 